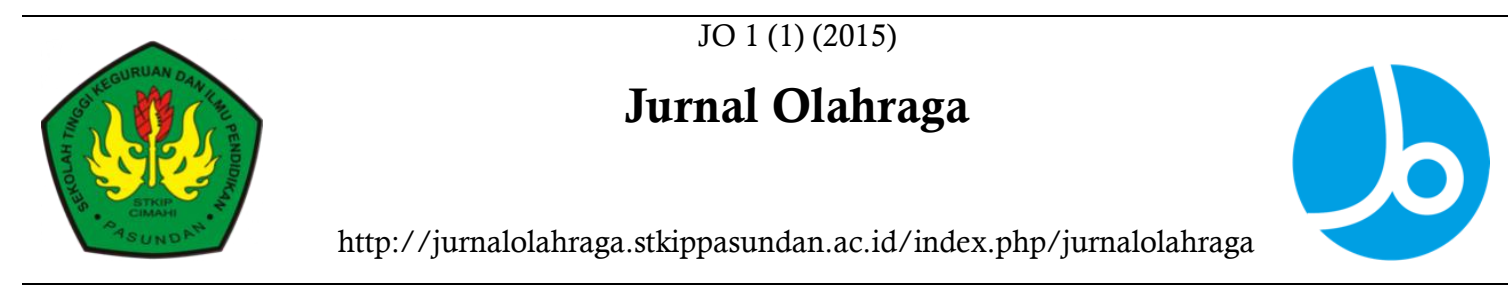

\title{
Pengaruh Media Pembelajaran Berbasis Multimedia terhadap Minat Belajar Mahasiswa STKIP Pasundan
}

\author{
Euis Karwati
}

STKIP Pasundan, Indonesia

\begin{tabular}{l} 
Info Artikel \\
\hline Sejarah Artikel: \\
Diterima Januari 2015 \\
Disetujui Maret 2015 \\
Dipublikasikan April 2015 \\
\hline Keywords: \\
Media Pembelajaran Berbasis \\
Multimedia, Minat Belajar \\
Mahasiswa \\
\hline
\end{tabular}

\begin{abstract}
Abstrak
STKIP Pasundan adalah sebuah perguruan tinggi yang berfokus pada menghasilkan pendidik dan tenaga kependidikan. Berdasarkan pengamatan dan wawancara diperoleh temuan bahwa mahasiswa di STKIP Pasundan memiliki minat belajar yang rendah. Media pembelajaran berbasis multimedia diyakini dapat meningkatkan minat siswa perguruan tinggi di STKIP Pasundan untuk belajar. Penelitian ini bertujuan untuk mengetahui bagaimana media pembelajaran berbasis multimedia, bagaimana minat siswa dalam belajar, dan juga untuk menganalisis apakah ada pengaruh dari pembelajaran media berbasis multimedia terhadap minat belajar mahasiswa di STKIP Pasundan. Metode yang digunakan adalah deskriptif dan verifikasi. Sampel adalah 120 mahasiswa STKIP Pasundan. Teknik pengambilan sampel menggunakan simple randomsampling (SRS). Penelitian menggunakan instrumen kuesioner. Analisis menggunakan analisis regresi linier yang menggunakan SPSS versi 21. Berdasarkan hasil ini, dapat disimpulkan bahwa media pembelajaran berbasis multimedia berada pada kategori tinggi, sedangkan minat siswa untuk belajar adalah kategori sedang. Selain itu, thetelahmenemukan pembelajaran media berbasis multimediahas yang berdampak positif dan signifikan terhadap minat mahasiswa dalam belajar. Dengan demikian, pembelajaran media berbasis multimedianeeds perlu ditingkatkan karena terbukti mampu meningkatkan minat siswa dalam belajar di STKIP Pasundan.
\end{abstract}

\begin{abstract}
STKIP Pasundan is a college that focuses on produce educators and education personnel. Based on observations and interviews obtained
\end{abstract}




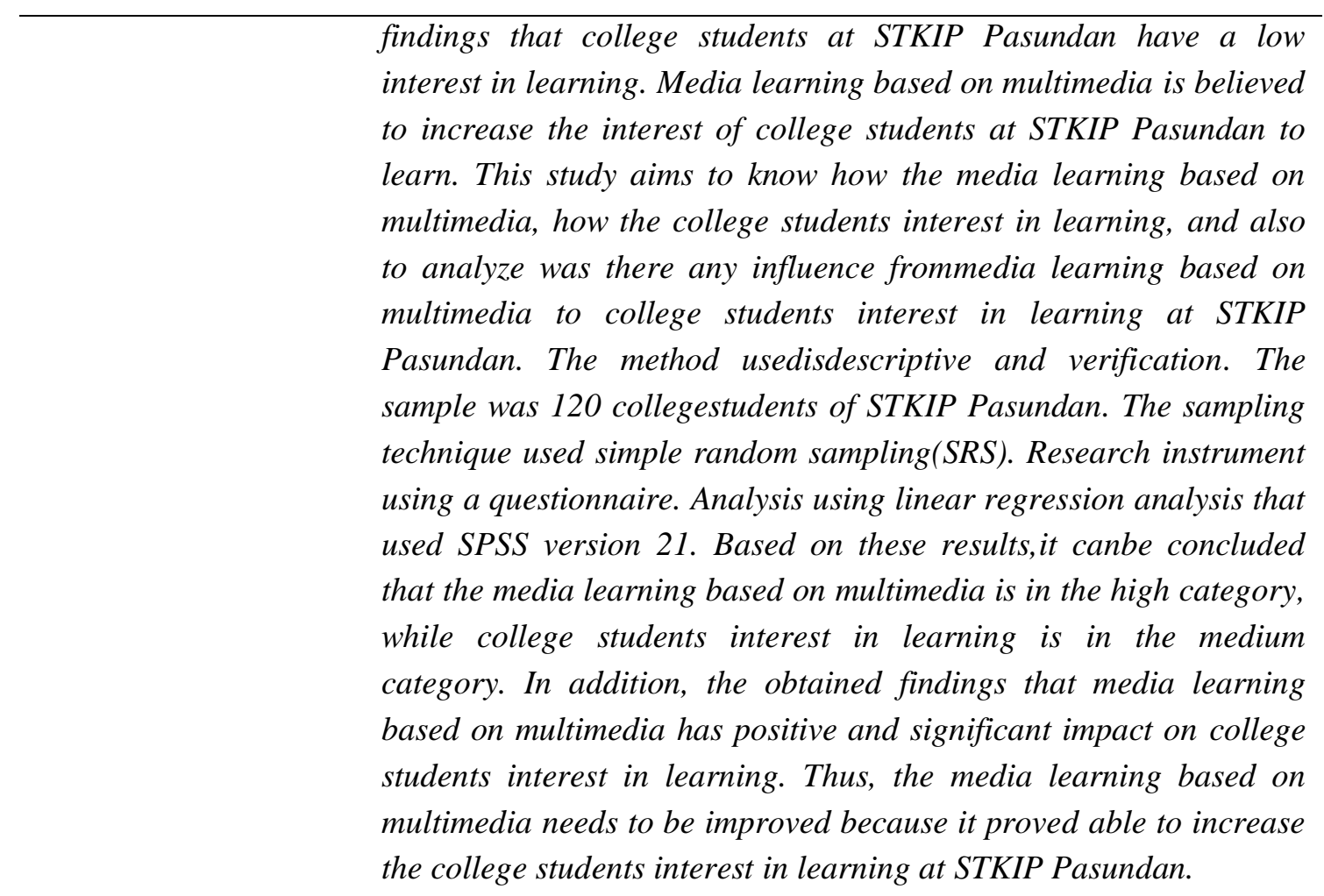

(C) 2015 STKIP Pasundan

Under the license CC BY-SA 4.0

$凶$ Alamat korespondensi:

E-mail:

\section{PENDAHULUAN}

Globalisasi telah menghadirkan banyak perubahan, terutama di bidang teknologi dan informasi. Teknologi dan informasi saat ini telah menjadi bagian tidak terpisahkan dari kehidupan bermasyarakat, bahkan perkembangan teknologi dan informasi juga telah banyak mempengaruhi perkembangan pendidikan dewasa ini. Dalam dunia pendidikan, pemanfaatan teknologi dan informasi menjadi bagian penting dalam proses pembelajaran di kelas, bukan hanya menyangkut kurikulum, namun juga menyangkut media pembelajaran.

Sistem pembelajaran konvensional dianggap tidak sesuai lagi dengan
ISSN 2442-9661 (cetak) perkembangan jaman, selain disebabkan adanya pergeseran pendidikan yang tadinya berfokus pada dosen menjadi berfokus pada mahasiswa dan lingkungan yang ada disekitarnya. Banyak mahasiswamerasa bahwa sistem pembelajaran konvensional tidak menarik dan tidak mampu menumbuhkan minat mereka untuk terus belajar. Sehingga kehadiran teknologi dan informasi menjadi solusi penting untuk menumbuhkan minat belajar mahasiswa.

Gambaran mengenai minat belajar mahasiswa yang masih rendah apabila perkuliahan masih menggunakan sistem konvensional dapat disimak dari hasil observasi dan wawancara yang telah 
dilakukan oleh penulis terhadap mahasiswa di STKIP Pasundan. Berdasarkan hasil observasi dan wawancara yang telah dilakukan oleh penulis, dapat disimpulkan gejala-gejala yang berkenaan dengan minat yang rendah dari mahasiswa untuk mengikuti perkuliahan di kelas, diantaranya adalah: Banyaknya mahasiswa yang tidak hadir untuk mengikuti perkuliahan di kelas, kalaupun mahasiswa hadir untuk mengikuti perkuliahan, mereka pada umumnya hadir bukan karena kesadaran untuk belajar, namun hadir hanya untuk memenuhi ketentuan syarat minimal kehadiran untuk UTS dan UAS; Mahasiswa merasa bosan dalam mengikuti proses perkuliahan, hal tersebut dapat disimak dari banyaknya mahasiswa yang menguap pada saat mengikuti proses perkuliahan di kelas; selain dua gejala tersebut gejala lainnya adalah mahasiswa sering keluar kelas dengan alasan pergi ke toilet, padahal mereka justru diam diluar kelas.

Berkaitan dengan fenomena tersebut, maka kecanggihan teknologi dan informasi telah menghadirkan media pembelajaran berbasis mulitmedia, dimana media pembelajaran berbasis multimedia diharapkan mampu meningkatkan minat mahasiswa untuk terus belajar. Media pembelajaran berbasis multimedia yang digunakan dapat berupa audio (suara, musik), animasi, video, teks, grafik, dan gambar yang digunakan sebagai alat untuk menyampaikan materi pembelajaran bagi mahasiswa, sehingga mampu merangsang minat mahasiswa untuk belajar.

Berdasarkan uraian tersebut, maka penelitian ini secara garis besar membahas tiga rumusan masalah, yaitu: a) Bagaimanamedia pembelajaran berbasis multimedia yang digunakan di STKIP Pasundan; b) Bagaimana minat belajar mahasiswa di STKIP Pasundan; dan c) Seberapa kuat pengaruh media pembelajaran berbasis multimedia terhadap minat belajar mahasiswa di STKIP Pasundan.

Kata media sendiri berasal dari bahasa latin dan merupakan bentukjamak dari kata "medium"yang secara harfiah berarti perantara ataspengantar. Media adalah perantara atau pengantar pesan dari pengirimke penerima pesan. Sanaky (2009:4) menyatakan bahwa mediapembelajaran adalah sarana pendidikan yang dapat digunakan sebagaiperantara dalam proses pembelajaran untuk mempertinggi efektifitasdan efisiensi dalam mencapai tujuan pengajaran. Notoamodjo (2003:71) menyatakan bahwa mediapembelajaran adalah alat-alat yang digunakan oleh pendidik dalammenyampaikan bahan pengajaran. Alat bantu ini lebih sering disebutalat peraga, karena berfungsi membantu dan memperagakan sesuatudalam proses pembelajaran.

Berdasarkan pendapat tersebut dapat disimpulkan bahwa mediapembelajaran merupakan sarana yang digunakan oleh dosen untuk menyampaikan materi pembelajaran, 
sehingga mahasiswa akan terbantu untuk dapat memahami materi pembelajaran dengan lebih baik lagi. Bahkan Sudjana dan Rivai (2002:2) menyatakan beberapa manfaat penggunaan media pembelajaran, yaitu:
a. Pengajaran akan lebih menarik perhatian mahasiswa sehingga dapatmenumbuhkan motivasi belajar;
b. Bahan pengajaran akan lebih jelas maknanya sehingga dapat lebih dipahami oleh mahasiswa;
c. Metode mengajar akan lebih bervariasi;

d. Mahasiswa melakukan kegiatan belajar, seperti mengamati, melakukan, dan mendemonstrasikan.

Setelah memahami apa yang dimaksud dengan media pembelajaran, maka selanjutnya kita akan memahami apa yang dimaksud dengan multimedia. Turban dkk (2002:15) menyatakan bahwa multimedia merupakan kombinasi paling sedikit duamedia input atau output dari data, media tersebut dapat berupa audio (suara, musik), animasi,video, teks, grafik, dan gambar. Lebih lanjut lagi Robin dan Linda (2001:21) menyatakan bahwa multimedia merupakan alat yang dapat menciptakan presentasi yang dinamis dan interaktif yangmengkombinasikan antara teks, grafik, animasi, audio dan gambar video.

Berdasarkan uraian tersebut, dapat disimpulkan bahwa media pembelajaran berbasis multimedia adalah media pembelajaran yang memanfaatkan perkembangan teknologi dan informasi yang berbentuk audio, animasi, video, teks, grafik, gambar, dan lain sebagainya, yang digunakan untuk menyampaikan materi pembelajaran sehingga mahasiswa mampu memahami materi pembelajaran dengan baik sesuai dengan tujuan intruksional pembelajaran.

Minat belajar mahasiswa perlu mendapatkan perhatian yang memadai. Djamarah (2008:166) menyatakan bahwa minat berarti kecenderungan yang menetap. Seseorang yangberminat terhadap aktivitas akan memperhatikan aktivitas itu secarakonsisten dengan rasa senang. Sujanto (2004:92) menyatakan bahwa minatsebagai suatu pemusatan perhatian yang tidak sengaja yang terlahirdengan penuh kemauan dan tergantung dari bakat danlingkungannya. Pernyataan tersebut menjelaskan bahwa minatmerupakan pemusatan perhatian. Witherington (Buchori, 1991:135) menyatakan bahwa minat merupakan kesadaran seseorang terhadap suatu obyek, seseorang, soal, atau situasi yang bersangkutan dengandirinya. Selanjutnya minat harus dipandang sebagai suatu sambutanyang sadar dan kesadaran itu disusul dengan meningkatnya perhatianterhadap suatu obyek. Djaali (2007:121) menyatakan bahwa minat adalah rasa lebih suka danrasa keterikatan pada sesuatu hal atau aktivitas tanpa ada yangmenyuruh. Pernyataan tersebut mengidentifikasikan bahwa orang yangberminat akan ada rasa tertarik. Tertarik 
dalam hal tersebut merupakanwujud dari rasa senang terhadap sesuatu.

Berdasarkan beberapa pendapat tersebut dapat disimpulkan bahwa minat belajar mahasiswa adalah kecenderungan mahasiswa untuk terlibat secara konsisten dan berkesinambungan dalam belajar. Minat tersebut dibangun atas perhatian dan perasaan yang senang. Lebih lanjut lagi Dalyono (2001:56-57) menyatakan bahwa minat dapat timbulkarena daya tarik dari luar dan juga datang dari dalam hati sanubari. Minatyang besar terhadap sesuatu merupakan modal yang besar, artinya untuk mencapai/memperoleh benda atau tujuan yang diminati tersebut. Minat belajar yang besar cenderung menghasilkan prestasi yangtinggi.

Syah (2002:129) menyatakan bahwa minat dapat mempengaruhi kualitas pencapaian hasil belajar mahasiswa dalam perkuliahan. Dosen seyogyanya membangkitkan minat mahasiswa untuk menguasai pengetahuan yang terkandung dalam bidang studinya dengan cara yang kurang lebih sama dengan membangun sikapyang positif. Winkel (1983:30) menyatakan bahwa perasaan senang akan menimbulkanminat pula, yang diperkuat lagi oleh sikap yang positif. Perasaan tidak senang akan menghambat dalam belajar, karena tidakmelahirkan sikap yang positif dan tidak menunjang minat dalambelajar.
Minat belajar dalam penelitian ini akan diukur dengan menggunakan indikator sebagai berikut:

Perasaan Senang.

Ahmadi (1991:36) menyatakan bahwa perasaan adalah peryataan jiwa yangsedikit banyak bersifat subyektif dalam merasakan senang atau tidaksenang. Suryabrata (2002:66) menambahkan bahwa gejala psikis yang bersifatsubyektif yang umumnya berhubungan dengan gejalamengenal dan dialami dalam kualitas senang atau tidak senang dalamberbagai taraf. Penilaian subjek terhadap sesuatu objek membentukperasaan subjek yang bersangkutan. Karena itu perasaan padaumumnya bersangkutan dengan fungsi mengenali, artinya perasaandapat timbul karena mengamati, menanggap, membayangkan, mengingat atau memikirkan sesuatu.

Perhatian.

Suryabrata (2002:14) menyatakan bahwa perhatian adalah pemusatan tenaga psikis tertuju kepada suatu obyek atau banyak sedikitnya kesadaran yang menyertai sesuatu aktivitas yang dilakukan. Lebih lanjut Baharudin (2009:178) menyatakan bahwa perhatian merupakan pemusatan atau konsentrasi dari seluruh aktivitas individu yang ditujukan kepadasuatu sekumpulan objek.

Aktivitas.

Ali dan Lukman (1996:26) menyatakan bahwa aktivitas adalah keaktifan ataukegiatan. Aktivitas yang dimaksud adalah 
keaktifan atau partisipasilangsung dalam suatu kegiatan. Pendapat ini didukung olehSuryabrata (2002:72) yang menyatakan bahwa aktivitas adalah banyak sedikitnyaorang menyatakan diri, menjelmakan perasaan dan pikiranpikirannyadalam tindakan yang spontan.

\section{METODE}

Unit analisis dalam penelitian ini adalah mahasiswa STKIP Pasundan. Berdasarkan hasil penarikan sampel dengan menggunakan rumus Slovin, diperoleh unit analisis sebesar 120 mahasiswa STKIP Pasundan yang menjadi sampel penelitian. Instrumen utama yang digunakan dalam penelitian ini adalah angket yang disebarkan kepada 120 mahasiswa STKIP Pasundan yang terpilih menjadi sampel.

Penelitian ini menggunakan dua jenis analisis, yaitu analisis deskriptif dan analisis verifikatif. Analisis deskriptif digunakan untuk melihat faktor penyebab sedangkan analisis verifikatif menitikberatkan pada pengungkapan perilaku variabel yang diteliti. Penelitian ini terdiri dari jaringan variabel yang mempunyai keterkaitan satu sama lainnya. Untuk dapat menganalisis secara lebih mendalam, maka perlu dideteksi hubungan antaravariabel yang diteliti.
Sebelum data dianalisis lebih mendalam, terlebih dahulu digunakan uji asumsi normalitas dan uji homogenitas. Uji asumsi normalitas digunakan untuk mengetahui apakah dalam sebuah model regresi, nilai residu dari model regresi tersebut mempunyai distribusi yang normal. Jika distribusi dari nilai-nilai residual tersebut tidak dapat dianggap berdistribusi normal, maka dikatakan ada masalah terhadap asumsi normalitas (Santoso, 2012:361). Sedangkan uji homogenitas dimaksudkan untuk memperlihatkan bahwa dua atau lebih kelompok data sampel berasal dari populasi yang memiliki variansi yang sama.

Teknik analisis data dan pengujian hipotesis yang digunakan dalam penelitian ini ialah menggunakan regresi linear dengan bantuan program komputer SPSS versi 21.00. Sugiyono (2010:210) menyatakan bahwa analisis regresi linier digunakan oleh peneliti apabila peneliti bermaksud meramalkan bagaimana keadaan (naik turunnya) variabel dependen (kriterium), apabila variabel independen sebagai faktor prediktor dimanipulasi (dinaikturunkan nilainya). Penelitian ini terdiri atas dua variabel, yaitumedia pembelajaran berbasis multimedia (X) dan minat belajar 
mahasiswa (Y), maka bentuk persamaan regresi $\mathrm{Y}$ atas $\mathrm{X}$ adalah sebagai berikut:

$$
\hat{Y}=a+b x
$$

\section{Keterangan}

a : $Y$ pintasan (nilai $\hat{Y}$ bila $x=0$ )

$\mathrm{b}$ : Kemiringan dari garis regresi (kenaikan atau penurunan Ŷuntuk setiap perubahan satu satuan atau koefisien regresi, mengukur besarnya pengaruh $\mathrm{X}$ terhadap Y jika X naik satu unit).

$\mathrm{X}$ :Nilai tertentu dari variabel bebas

$\mathrm{Y}$ :Nilai yang diukur dari variabel terikat

\section{HASIL DAN PEMBAHASAN}

\section{Media Pembelajaran Berbasis \\ Multimedia di STKIP Pasundan}

Berdasarkan hasil pengolahan data, diketahui bahwa media pembelajaran berbasis multimedia di STKIP Pasundan berada dalam kategori yang tinggi. Indikatorvideo memperoleh skor tertinggi, sedangkan indikator audio memperoleh skor paling rendah. Dengan demikian, dapat disimpulkan bahwa video merupakan indikator yang paling penting dalam media pembelajaran berbasis multimedia, karena dengan menggunakan video maka mahasiswa menjadi mudah memahami materi pembelajaran yang disampaikan. Rendahnya kontribusi audiodalam media pembelajaran berbasis multimedia dikarenakan audiohanya bersifat suara yang tidak bisa memudahkan mahasiswa untuk memvisualisasikan materi perkuliahan secara berkesinambungan.

\section{Minat Belajar Mahasiswa STKIP Pasundan.}

Berdasarkan hasil pengolahan data, diketahui bahwa minat belajar mahasiswa
STKIP Pasundan berada dalam kategori yang sedang. Indikator perasaaan senangmemperoleh skor tertinggi, sedangkan indikator aktivitas memperoleh skor paling rendah. Dengan demikian, dapat disimpulkan bahwa perasaan senang merupakan indikator yang paling penting dalam minat belajar mahasiswa, karena dengan perasaan yang senang mahasiswa akan mengikuti setiap proses dalam pembelajaran secara baik. Rendahnya kontribusi aktivitas dalam minat belajar mahasiswa dikarenakan aktivitas berkenaan dengan keaktifan atau partisipasi langsung dalam suatu kegiatan.

\section{Pengaruh Media Pembelajaran}

Berbasis Multimedia terhadap

Minat Belajar Mahasiswa STKIP

Pasundan.

Tabel 1

Hasil Uji Normalitas Data One-Sample Kolmogorov-Smirnov Test

\begin{tabular}{|c|c|c|c|}
\hline & $\begin{array}{c}\text { Media } \\
\text { Pembelajara } \\
\text { n Berbasis } \\
\text { Multimedia }\end{array}$ & $\begin{array}{l}\text { Minat } \\
\text { Belajar }\end{array}$ \\
\hline \multirow{3}{*}{$\begin{array}{c}\text { Normal } \\
\text { Parameters }\end{array}$} & $\mathrm{N}$ & 120 & 120 \\
\hline & Mean & 60.1417 & 40.4667 \\
\hline & Std. Deviation & 6.72671 & 4.87134 \\
\hline \multirow{3}{*}{$\begin{array}{c}\text { Most } \\
\text { Extreme } \\
\text { Difference }\end{array}$} & Absolute & .058 & .073 \\
\hline & Positive & .055 & .073 \\
\hline & Negative & -.058 & -.073 \\
\hline \multirow{2}{*}{\multicolumn{2}{|c|}{$\begin{array}{l}\text { Kolmogorov-Smirnov Z } \\
\text { Asymp. Sig. (2-tailed) }\end{array}$}} & .640 & .803 \\
\hline & & .807 & .539 \\
\hline
\end{tabular}
normalitas suatu distribusi data yang telah dikembangkan oleh para ahli, salah satunya dengan menggunakan teknik Kolmogorov Smirnov (Sujianto, 2007:71). Hasil pengujian normalitas data dengan menggunakan Kolmogorov Smirnov diperoleh hasil seperti 
disajikan dalam Tabel 1. Berdasaran hasil pengujian tersebut, diketahui bahwa data dalam variabelmedia pembelajaran berbasis multimedia dan minat belajar mahasiswa terdistribusi secara normal karena nilai signifikansinya di atas 0,05 sehingga layak untuk digunakan sebagai bahan dalam tahap pengolahan data berikutnya. Setelah dilakukan uji normalitas data, selanjutnya disajikan uji homogenitas data. Uji homogenitas dimaksudkan untuk memperlihatkan bahwa dua atau lebih kelompok data sampel berasal dari populasi yang memiliki variansi yang sama.

Tabel 2

Hasil Uji Homogenitas Data

Levene's Test of Equality of Error Variances ${ }^{\text {a }}$

Dependent Variable: Minat Belajar

\begin{tabular}{|r|r|r|r|}
\hline \multicolumn{4}{|c|}{ Dependent Variable: Minat Belajar } \\
\hline $\mathrm{F}$ & $\mathrm{df1}$ & $\mathrm{df2}$ & \multicolumn{1}{c|}{ Sig. } \\
\hline 2.379 & 28 & 91 & .066 \\
\hline
\end{tabular}

Tests the null hypothesis that the error variance of the dependent variable is equal across groups.

a. Design: Intercept + VAR00001

Pada kolom Sig. menunjukkan nilai sign. di atas 0,05, yaitu 0,066. Dengan demikian data penelitian sudah bersifat homogen. Setelah diketahui data bersifat normal dan homogen, selanjutnya dilakukan analisis regresi. Analisis regresi digunakan untuk mengetahui ada tidaknya pengaruh media pembelajaran berbasis multimedia terhadapminat belajar mahasiswa STKIP Pasundan. Teknik analisis yang digunakan dalam penelitian ini adalah analisis regresilinear dengan menggunakan aplikasi sotware SPSS 21.00. Berdasarkan hasil pengujian, diperoleh hasil seperti disajikan dalam Tabel 3.

Tabel 3

Uji Signifikansi Pengaruh Media

Pembelajaran Berbasis Multimedia terhadap Minat Belajar

ANOVA $^{\mathrm{a}}$

\begin{tabular}{|c|c|c|c|c|c|}
\hline Model & $\begin{array}{l}\text { Sum of } \\
\text { Squares }\end{array}$ & df & $\begin{array}{c}\text { Mean } \\
\text { Square }\end{array}$ & $\mathrm{F}$ & Sig. \\
\hline $\begin{array}{l}\text { Regre } \\
\text { ssion } \\
\text { Resid } \\
\text { ual } \\
\text { Total }\end{array}$ & $\begin{array}{l}1743.587 \\
1080.280 \\
2823.867\end{array}$ & $\begin{array}{r}1 \\
118 \\
119\end{array}$ & $\begin{array}{r}1743.587 \\
9.155\end{array}$ & $\begin{array}{c}190.45 \\
4\end{array}$ & $.000^{b}$ \\
\hline
\end{tabular}

b. Predictors: (Constant), Media Pembelajaran Berbasis Multimedia

Berdasarkan Tabel 3, dapat diketahuitingkat signifikansi sebesar 0,000. Karena probabilitas0,000jauh lebih kecil dari 0,05, makadapat disimpulkan bahwa media pembelajaran berbasis multimediaberpengaruh terhadap minat belajar. Berdasarkan hasil tersebut, selanjutnya dihitung persamaan regresi. Persamaan regresi digunakan untuk melakukan prediksi seberapa tinggi nilai variabel minat belajar bila variabel media pembelajaran berbasis multimedia dimanipulasi. Hasil perhitungan dengan menggunakan software SPSS 21.00. disajikan dalam Tabel 4. 
Tabel 4

Koefisien Regresi Pengaruh Media

Pembelajaran Berbasis Multimedia terhadap Minat Belajar

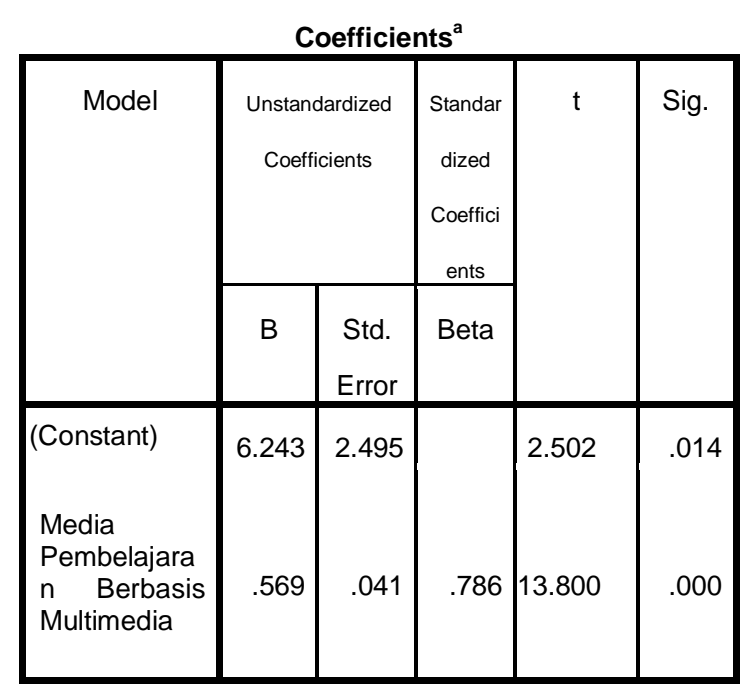

a. Dependent Variable: Minat Belajar

Berdasarkan Tabel 4, dapat dijelaskan bahwakonstanta sebesar 6,243menyatakan jika tidak ada media pembelajaran berbasis multimedia, maka minat belajar sebesar 6,243. Sedangkan koefisien regresi sebesar 0,569menyatakan bahwa setiap penambahan satu kali untuk media pembelajaran berbasis multimedia maka minat belajar akan meningkat sebesar 0,569.Sebaliknya, jika media pembelajaran berbasis multimedia turun satu kali, maka minat belajar juga diprediksi akan mengalami penurunan sebesar 0,569.

Persamaan regresi linier sederhana antaramedia pembelajaran berbasis multimedia dan minat belajar adalah:

Minat Belajar $=6,243+0,569$ Media Pembelajaran Berbasis Multimedia

$$
\mathrm{Y}=6,243+0,569 \mathrm{X}
$$

Pengujian signifikansi konstanta dapat dilakukan dengan membandingkan nilai $\mathrm{t}$ tabel

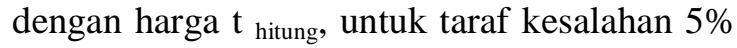
uji satu pihak dengan $\mathrm{dk}=\mathrm{n}-1$, maka diperoleh $\mathrm{t}$ tabel sebesar 1,66. Karena nilai $\mathrm{t}$ hitung lebih besar dari pada $t$ tabel $(13,800>1,66)$, maka hipotesis diterima. Hal ini berarti terdapat pengaruh positifdan signifikan dari media pembelajaran berbasis multimedia terhadap minat belajar mahasiswa STKIP Pasundan.

Besarnya pengaruh media pembelajaran berbasis multimedia terhadap minat belajar dapat diketahui melalui hasil uji koefisien determinasi. Koefisien determinasi diketahui dengan cara mengkuadratkan koefisien korelasi yang telah ditemukan, dan selanjutnya dikalikan dengan 100\% (Sugiyono, 2010:154).

\section{Tabel 5}

\section{Koefisien Determinasi Pengaruh Media Pembelajaran Berbasis Multimedia terhadap Minat Belajar}

\begin{tabular}{|c|c|r|r|r|}
\hline $\begin{array}{c}\text { Mode } \\
\mathrm{I}\end{array}$ & $\mathrm{R}$ & $\begin{array}{c}\mathrm{R} \\
\text { Square }\end{array}$ & $\begin{array}{c}\text { Adjusted } \\
\text { R Square }\end{array}$ & $\begin{array}{c}\text { Std. Error of } \\
\text { the Estimate }\end{array}$ \\
\hline 1 & $.889^{\mathrm{a}}$ & .790 & .614 & 3.02571 \\
\hline
\end{tabular}
nilai R (korelasi) sebesar 0,790. Kontribusi media pembelajaran berbasis multimedia terhadap minat belajar mahasiswa sebesar 0,790atau $79 \%$, dan sisanya sebesar $21 \%$ dipengaruhi oleh faktor lain yang tidak diteliti dalam penelitian ini, misalnya strategi pembelajaran. Kontribusi tersebut menunjukkan bahwa pengaruh media pembelajaran berbasis multimedia terhadap minat belajar berada pada klasifikasi yang 
kuat, karena nilai tersebut berada pada kisaran 0,600-0,799.

\section{KESIMPULAN}

Berdasarkan hasil penelitian dan analisa data dapat disimpulkan bahwa (1) Media pembelajaran berbasis multimedia berada dalam kategori tinggi. Indikator video memperoleh skor tertinggi, sedangkan indikator audio memperoleh skor paling rendah. (2) Minat belajar mahasiswa STKIP Pasundan berada dalam kategori yang sedang. Indikator perasaaan senangmemperoleh skor tertinggi, sedangkan indikator aktivitas memperoleh skor paling rendah. (3) Media pembelajaran berbasis multimedia berpengaruh positif dan signifikan terhadap minat belajar mahasiswa STKIP Pasundan. Pengaruh tersebut berada dalam kategori yang kuat. Semakin interaktif media pembelajaran berbasis multimedia dikembangkan, maka semakin tinggi minat belajar mahasiswa STKIP Pasundan.

\section{DAFTAR PUSTAKA}

Ahmadi, Abu. (1991). Psikologi Umum. Bandung: Mandar Maju.

Ali dan Lukman. (1996). Kamus Besar Bahasa Indonesia (Edisi II). Jakarta: Balai Pustaka.

Baharudin. (2009). Psikologi Pendidikan: Refleksi Teoritis.Yogyakarta: Ar-Ruzz Media.

Buchori. (1991). Psikologi Pendidikan. Jakarta. PT. Aksara Baru.
Dalyono, M. (2001). Psikologi Pendidikan. Jakarta: PT. Rineka Cipta.

Djaali, (2007). Psikologi Pendidikan. Jakarta: PT. Bumi Aksara.

Djamarah, Syaiful Bahri. (2008). Psikologi Belajar. Jakarta: PT. Rineka Cipta.

Notoatmodjo, Soekidjo (2003). Pengembangan Sumber Daya Manusia. Jakarta: PT. Asdi Mahasatya.

Robin dan Linda. (2001). Pengantar Multimedia untuk Media Pembelajaran. Yogyakarta: Andi.

Sanaky, Hujair. (2009). Media Pembelajaran. Yogyakarta: Safiria Insani Press.

Santoso, Singgih. (2012). SPSS: Mengolah Data Statistik secara Profesional.Jakarta: Elex Media Komputinda.

Sudjana, Nana dan Ahmad Rivai. (2002). Media Pengajaran. Bandung: Sinar Baru Algensindo.

Sugiyono. (2010). Metode Penelitian Administrasi. Bandung: CV. Alfabeta.

Sujanto, Agus. (2004). Psikologi Umum. Jakarta: PT. Rineka Cipta.

Suryabrata. (2002). Psikologi Pendidikan. Jakarta: PT. Raja Grafindo Persada.

Syah, Muhibbin. (2002). Psikologi Pendidikan dalam Pendekatan Baru. Bandung: PT. Remaja Rosdakarya.

Turban, Efraim, dkk (2002). Introduction to Information Technology. New York: John Wiley \& Sons, Inc.

Winkel, S. J.. (1983). Psikologi Pendidikan dan Evaluasi Belajar. Jakarta: PT. Gramedia. 